\title{
Empowering Pasifika Students to Express their Identities through Visual Arts in New Zealand Secondary Schools: The Role of Euro-descendent Teachers
}

\author{
Jill Smith \\ The University of Auckland \\ New Zealand
}

ABSTRACT: The greatest numbers of young people in New Zealand are from Pasifika peoples' ethnic groups. In contrast, art teachers in secondary schools are predominantly European. Research conducted in 2015, which investigated how art teachers are responding to the increasing diversity of students, uncovered important insights. This article provides "snapshots" of how four European-New Zealand art teachers, who work in schools where Pasifika students comprise the largest ethnic group, are empowering them to express themselves within their cultural milieu. Articulated through the voices of the art teachers, the stories of these students are visualized through examples of their art works.

KEYWORDS: secondary school, visual arts, Pasifika identity, New Zealand, art education

\author{
Background to the Study \\ The Study Design \\ Findings \\ Discussion \\ Conclusions \\ Notes \\ References \\ Author Contact
}

\section{Background to the Study}

This small-scale study, conducted in 2015 in secondary schools in Auckland, New Zealand, investigated how art teachers are responding to the increasing ethnic and cultural diversity of their students. The study was motivated by my role as a European-New Zealand pre-service art teacher educator in the secondary school sector and was informed by observations, made during school visits, about the widening demographic contrast between students and art teachers. The study is contextualized within the national curriculum, demographic statistics, literature on culturally inclusive visual arts education, and research about Pasifika students as learners. The term "Pasifika" is unique to New 
Zealand. It is used to describe migrants from the Pacific region and their descendants who now call New Zealand home (Ministry of Education [MoE], 2010). Auckland, the location for the study, is described as the "Polynesian Capital of the World" (World Directory of Minorities and Indigenous Peoples, 2015).

\section{Cultural Policy in National Curriculum}

Visual arts education in New Zealand secondary schools is informed by The New Zealand Curriculum (MoE, 2007). The Arts are cited as one of eight Learning Areas alongside English, Health and Physical Education, Learning Languages, Mathematics and Statistics, Science, Social Sciences, and Technology (p. 17). The curriculum states that "the Arts are powerful forms of expression that recognize, value, and contribute to the unique bicultural and multicultural character of Aotearoa New Zealand" (p. 20) and that "European, Māori, Pasifika, Asian and other cultures add significant dimensions to New Zealand visual culture" (p. 21). The curriculum also contains eight principles: high expectations, Treaty of Waitangi, cultural diversity, inclusion, learning to learn, community engagement, coherence, and future focus, all of which "embody beliefs about what is important and desirable in school curriculum" (p. 9).

In 2012 the Education Review Office [ERO] (2012) evaluated the eight curriculum principles that should underpin all school decision-making. From evidence gained of each principle in the curriculum of 201 classrooms, cultural diversity ranked as "least evident" (p. 16). ERO concluded that "Cultural diversity has perhaps been overlooked as teachers focused on meeting bicultural, Treaty of Waitangi obligations" (p. 19). This comment aligns with the result of my previous research that multicultural visual arts education in secondary schools is complicated by New Zealand's position on biculturalism, and can affect art teachers' pedagogies (Smith, 2007, 2010). An aim of this present study was to determine whether this position had changed in 2015.

\section{Static versus Changing Demographics}

The 2013 New Zealand Census (Statistics New Zealand, 2014) identified an increasing contrast between the European adult population and the ethnically diverse youthful population. Of the 4,649.700 people living in New Zealand, nearly three-quarters (74\%) identified as European. ${ }^{1}$ The next largest groups were Māori (14.9\%), Asian (11.8\%), Pasifika (7.4\%) and Middle Eastern/Latin American/ African (1.2\%). ${ }^{2}$ By 2013 , Auckland city, the location for the study, had become home to one of the largest Pasifika populations in the world, with $67 \%$ of Pasifika peoples' ethnic groups living there, the majority being New Zealand-born (Royal Society of New Zealand, 2014). The Auckland Council (2013) also reported that Auckland had gained a more youthful population, with 
$45 \%$ under 20 years, the greatest numbers being Pasifika; that $88 \%$ of Auckland schools have $50 \%$ or more Pasifika students; and that in 30 years one in five people in Auckland are likely to be of Pacific descent.

Regular visits to secondary school art departments, over many years, confirm the increasing contrast between teachers and students. This resonates with international research that school populations in western nations are becoming more diverse while teachers continue to be White and female (Feistritzer, 2011; Landsman \& Lewis, 2006; Sleeter, 2008).

\section{Pedagogical Practices for Culturally Inclusive Visual Arts Education}

Issues of cultural pluralism, diversity, difference and anti-racism are comprehensively articulated in literature about multicultural education. While some theorists promote modernist conceptions, celebrating pluralism and affirming diversity (Desai \& Chalmers, 2007; Nieto \& Bode, 2012), others advocate postmodern conceptions such as social reconstructionist multiculturalism and teaching visual culture and material culture studies (Bolin \& Blandy, 2011; Duncum, 2008; Erickson, 2006; Freedman \& Stuhr, 2004). The latter challenge the dominant power and knowledge structures that tend to create socio-cultural inequities. A critical approach to policy and pedagogy, and an ethic that gives priority to equity and democracy as primary social objectives, is considered a way forward for an active engagement in cultural inclusion (Bianchi, 2011; Grant \& Sleeter, 2006; Hanley \& Noblit, 2009). These perspectives, supported by my position as a European-New Zealand art teacher educator working with predominantly Euro-descendent pre-service teachers, provided the foundation for the study. My aim was to ascertain secondary school art teachers' understandings of culturally inclusive pedagogies, and whether these affected students' outcomes. Although their research had been framed within the context of African American students, I sought evidence of Hanley and Noblit's (2009) claim that "culturally responsive pedagogy and racial identity are related to achievement and resilience" (p. 81).

\section{Teaching for Success with Pasifika Students}

Literature about Pasifika learners in schools informed the study. Ferguson, Gorinski, Wendt-Samu and Mara (2008) suggest that few opportunities are given to Pasifika students to create their own identities. They argue that Pasifika students tend to conform to, or rebel against, the identities that have been constructed for them and that this results in either passivity or rebellion in classrooms. These authors claim that schools, teachers, and other students need to support Pasifika learners to be themselves and to see themselves and their culture reflected in the classroom. Fletcher, Parkhill, Amosa, Leali'ie'e and O'Reagan (2009) found that "Pasifika students' literacy learning, and overall 
learning, was more likely to be enhanced when Pasifika values, language identities and cultural knowledge were made an implicit part of teaching and learning activities" (p. 24). Si'ilata (2014) maintains that teachers can learn how to teach Pasifika students by becoming knowledgeable about the languages and cultures of particular Pasifika ethnic groups, and having high expectations of these learners. No literature was located on how the visual arts, as a visual language and form of visual literacy, is being used by non-Pasifika art teachers to empower Pasifika students to achieve success.

New Zealand researchers assert that teaching is the most important factor in student achievement (Alton-Lee, 2003; Rubie-Davies, 2008). This requires teachers to take responsibility for every student, value diversity, respect students' cultures, have high expectations, and build on students' experiences. Nash (2004) concurs that achievement is affected by the degree to which a student's culture is respected, and the similarity between the culture of the community and the values of that school. Si'ilata $(2014$, p. 2) maintains that "Success for Pasifika peoples and their children should be considered holistically, relative to the multiple worlds they live in." These were factors I looked for in respect of Pasifika students' achievement through visual arts education.

\section{The Study Design}

Fifty-three Auckland secondary schools were approached to participate in the study. The criteria for school selection were location across the Auckland area, school type, and socio-economic decile. The latter is a measure of socioeconomic status in New Zealand education, primarily used to target funding and support to more needy schools. Pertinent to this research, the Auckland Council (2013) reported that $67.8 \%$ of Auckland's Pasifika students are in decile 1-3 schools, the lowest socio-economic ratings on a 1-10 scale. A requirement of the University of Auckland's Human Participants Ethics Committee was for the school principals to invite an art teacher to participate, rather than the teacher being approached by me.

The study was conducted in two stages: (1) an anonymous online questionnaire; and (2) an optional face-to-face interview. Rich baseline data were gathered in Stage 1. Although not reported in this article, which focuses specifically on Pasifika students, these data informed Stage 2. From the 28 art teachers who volunteered to be interviewed, 10 were randomly selected using the same criteria as for school selection. The art teachers were offered the option of bringing to their interviews examples of students' art works that they believed reflected their responsiveness to the ethnic and cultural diversity of the students they teach. The ethics process required permission from students and their parents/caregivers, prior to art works being brought to interviews and subsequently used in reporting the study. It was beyond the scope of this smallscale study to interview students, but it was anticipated that in-depth interviews 
with their art teachers, together with examples of their art works, could provide important insights.

\section{The Settings and Participants in the Study}

The ten art teachers who were interviewed taught across the range of decile 1-10 schools. The four who feature in this article taught in decile 1-3 secondary schools with large numbers of Pasifika students aged between 13 and 18. ${ }^{3}$ Their schools, hereafter referred to as Schools A-D, had a total enrolment of 4,810 students of which 3,147 were from Pasifika peoples' ethnic groups. Three art teachers were European-New Zealand and a fourth was European-New Zealand Māori. The ethics process required pseudonyms to be used to protect the identities of the teachers and their schools, but students' art works were permitted to be identified by their first names, ethnicity and age. Prior to the interviews, the teachers completed a spreadsheet detailing their professional and academic qualifications and the school's student ethnicity statistics. They also provided a copy of their school's mission or vision statement. These data informed the interviews and provided a rich introduction to the settings and participants.

\section{Data Collection through Interviews and Images}

Each art teacher was interviewed for up to three hours in their art department, followed by photographic documentation of students' art works. Data collected through the semi-structured, audio-recorded interviews were informed by the following elements: (a) the national curriculum policy on "cultural diversity"; (b) the demographic contrast between Pasifika students and European-New Zealand art teachers; (c) influences of the school's philosophy and mission/vision statement; and (d) how or whether the teachers enabled Pasifika students to express their identities through the visual arts. Underpinning the interviews was the key question, "How are art teachers in New Zealand responding to the increasing ethnic and cultural diversity of students in secondary schools?"

The decision to seek images of students' art works was based on literature about the theoretical grounding for using images as a powerful tool in research. Weber (2008) advocates for the "ability of images to evoke visceral and emotional responses in ways that are memorable, coupled with their capacity to help us empathize or see another's point of view" (p. 47). The inclusion of images also challenges prevailing modes of academic discourse (Leavy, 2009). The students' art works provided a critical component of this study. 


\section{Findings}

The findings are presented as four "snapshots" expressed through the voices of the art teachers, visualized through examples of art works by their year 11-13 Pasifika students, and shaped through my lens. Each snapshot provides insights into how the three European-New Zealand and one European-New Zealand Māori art teachers are empowering students to express their identities through the visual arts.

\section{Snapshot 1: School A}

Martin, a European-New Zealand male with a Bachelor of Visual Arts and Diploma in Teaching, had taught at School A for 12 years. This decile 1 state coeducational school had an enrolment of 1,268 students of whom 914 were Pasifika. Of these students, $70 \%$ were Tongan and Samoan, $10 \%$ Māori, and $12 \%$ Cook Islands Māori. The remaining $8 \%$ included four European students. In its vision statement, School A describes itself as "a dynamic learning community that is meeting the needs of its student population while maintaining the awareness of living in a rapidly changing society with diverse cultural needs."

When asked about curriculum expectations that address cultural diversity, Martin said, "You've got to be supremely aware as much as you can...you wouldn't survive in this school if you were culturally ignorant, if you couldn't pronounce the students' names, and if you didn't have some awareness of the lives they lead." Martin spoke passionately about his students. He described them as belonging solidly to the village community that the school is a part of, with religion being highly significant. "Church is like an extension of their village and their parents' culture... and nostalgia for the Islands is a big thing...you can tell they long to do Pasifika subject matter, especially the 15 to 18 year olds." Martin said that "cultural diversity is a huge part of everything you do because students will reject out of hand anything they don't like...to be honest, Pasifika culture is so omnipresent here it's not an issue...some students are so strongly patriotically Samoan that it's coming out of every pore."

Martin selected subject matter and techniques that he believed resonated with his students. He described how the three-color woodcut unit taught with year 11 students and illustrated by 15 year old Taniela's print in Figure 1a, appealed to them because of the physicality of making woodcuts, "because these students are quite big and physical...," cutting into the boards, and rolling out the ink.

The unit was called "taro graffito" to satisfy the urban side and satisfy the Island side. I thrashed taro (a root vegetable), got them to draw from actual taro all through the year...they liked it but got sick of taro and the whole thing of "you're an Islander therefore you must like taro because you eat it, therefore you've got to draw it." 
Martin confessed that one day he realized that using taro as subject matter wasn't culturally reflective of all the students or all the islands because it isn't grown everywhere, and that he needed to explore other directions. He said,

I gradually felt my way towards putting less emphasis on flat patterning and more on three-dimensional rendering. I wanted to satisfy the students' craving to do realistic portraits about themselves and others they connect with, nostalgia for the Islands, and their commitment to religion.

A section of 15-year-old Diamranase's portfolio, shown in Figure 1b, illustrates aspects of life in Samoa. His paintings draw attention to connections with family, growing and harvesting food, and the beauty of a Pacific sunset.

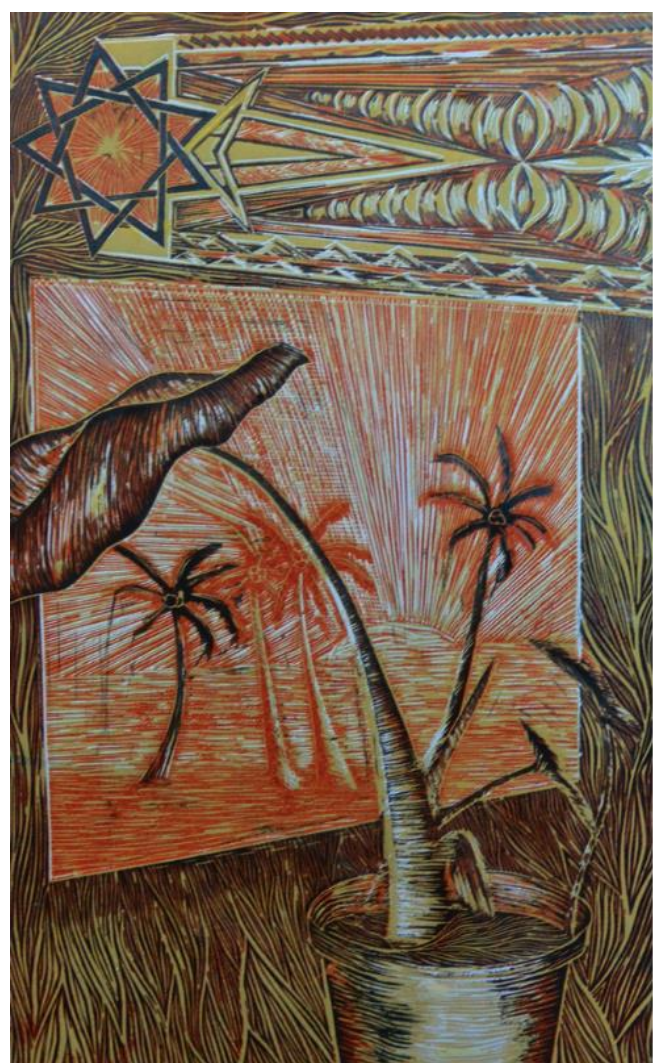

Figure 1a. Taniela, Tongan, 15
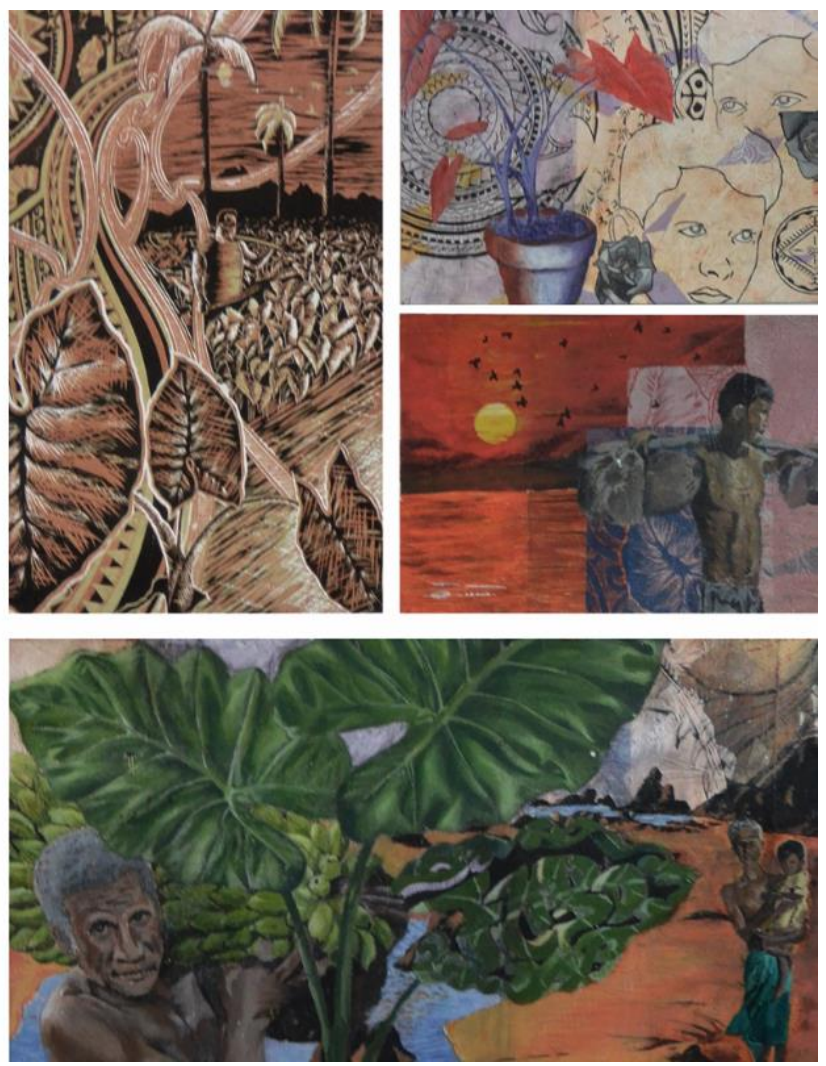

Figure 1b. Diamranase, Samoan, 15

Martin's art room was filled with portfolios, works in progress, plants in pots, and display areas featuring the art and art-making processes of "artist models." ${ }^{4}$ He spoke with great pride about his students' achievements; among them, he considered Grevel, a 17-year-old Samoan-Chinese boy, to be "a bit of a standout" (see Figure 2).

You can tell he's going places...he's got the top role in the school production, he's a top dancer... You watch them doing their hip hop thing and you can't take your eyes off Grevel. You can see from his ink and dye 
work that he's a genius. He's got the figure in a vignette, then in front of a pattern, and then it's like the pattern is giving birth to the figure. Isn't that clever? It's because he's a dancer and he thinks with his body.
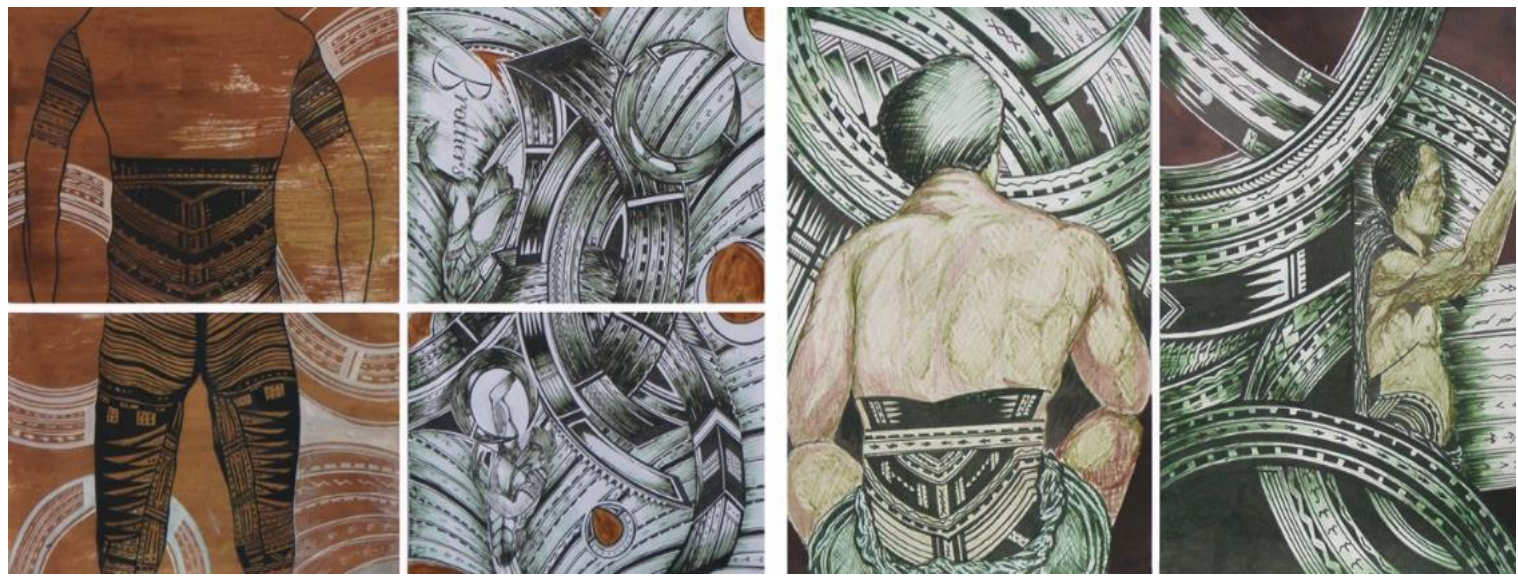

Figure 2. Grevel, Samoan-Chinese, 17

Martin was clearly at home in this environment, and I was curious to know whether students could tell he likes teaching them. He said, "The moment any teacher shows the faintest cynicism they're finished." He described the students as enthusiastic, bright and young, but added,

Some may have a sneering 'up you' kind of veneer but it's very, very shallow. They'll rebel against you and tell you that you're an old baldheaded so and so, but they're fresh and open and fun to be with...even though they can be lazy and drive me mad at times.

When asked about the importance of teacher disposition for a EuropeanNew Zealander like him teaching at School A, Martin said,

Well the school kind of chooses you. You wouldn't survive if you couldn't hack it with the students, you just wouldn't last and lots of people don't. If they come in thinking they can be missionaries or social workers, it's hell for them.

Martin had no illusions about the challenge of teaching in a decile 1 school. His mission was to push students' achievement in the visual arts, especially in years 11-13. For him, developing "visual literacy" was his best means of countering the lower language literacy among the Pasifika students. He concluded that "through their art these students can show who they are, what interests them, and what they can do."

As we finished photographing the students' art works a large group of 15to-16 year olds, predominantly Pasifka, arrived for the last class of the day. Noisily jostling into the art room arm-in-arm, joking with "sir" about his "lady visitor," I could see that the rapport Martin had with these students was built on 
mutual respect and a fond regard for each other. His gregarious personality sat well with them. It left me wondering in anticipation about my upcoming interview with Jacqui.

\section{Snapshot 2: School B}

Jacqui, head of art at School B, identified as European-New Zealand Māori. With a Bachelor of Visual Arts and Graduate Diploma in Secondary Teaching, she was in her tenth year of teaching. School B, a state co-educational school with a decile rating of 1 , had an enrolment of 922 students of which $77 \%$ were from Pasifika peoples' ethnic groups. Māori students comprised 19\%, and the remaining $4 \%$ included 24 European students. The school's mission statement was "To nurture in each individual a belief in the self, a commitment to achievement and the spirit of aroha (caring)." Core values were "acknowledgement of Māori as tangata whenua (the first people of the land), positive affirmation of cultures in the school, and respect for all."

The art department's mission statement was "to inspire in each student a creative outlet that will develop their confidence, support their wellbeing and help shape their personal identity in a positive way." The art program was scaffolded from years 9-13. When asked whether the cultural diversity or individual ethnicities of students was a key component in planning, Jacqui said, "At junior levels it isn't. These art courses are very compressed so we concentrate on giving students art making skills and building art terminology." She explained that the language literacy level was low in the school and was a key focus in every curriculum Learning Area. In art, literacy was approached through the curriculum strand, "Understanding the visual arts in context." Jacqui's priority was to develop students' "visual literacy" in all year levels.

The examples Jacqui brought to her interview were portfolios in progress by her year 13 painting class. She said, "It is at this level that the students, mostly 17-to-18 year olds, really want to make art about themselves." The subject matter, focus, style, and painting techniques employed by each student were distinctly different. Once students had selected the subject matter they wanted to explore, and what artists' works they were attracted to, Jacqui helped them locate "artist models" for inspiration.

A notable feature of art works made by girls in this class was a focus on their own image. In Vera's paintings in Figure 3, I surmised that she was representing her dual contexts through symbolic "text" (Cohen, 1985) and material culture signifiers (Bolin \& Blandy, 2011). The reflective girl, at left, in European dress, lips and nails painted scarlet, contrasts with how she has placed herself in the island context of Samoa. In the mixed media painting on the right, material cultural signifiers such as the fale (a place for gathering as a community), taro and breadfruit leaves, and a basket for gathering food, provide the backdrop for Vera. She wears a shawl decorated in Pasifika patterns and the hibiscus flower tucked behind her right ear signifies she is a single woman. I saw 
Vera's graphic technique of lines and blocks of color and sensitive use of dreamlike transparent paint as suggesting a sense of loss and longing, but also of belonging.
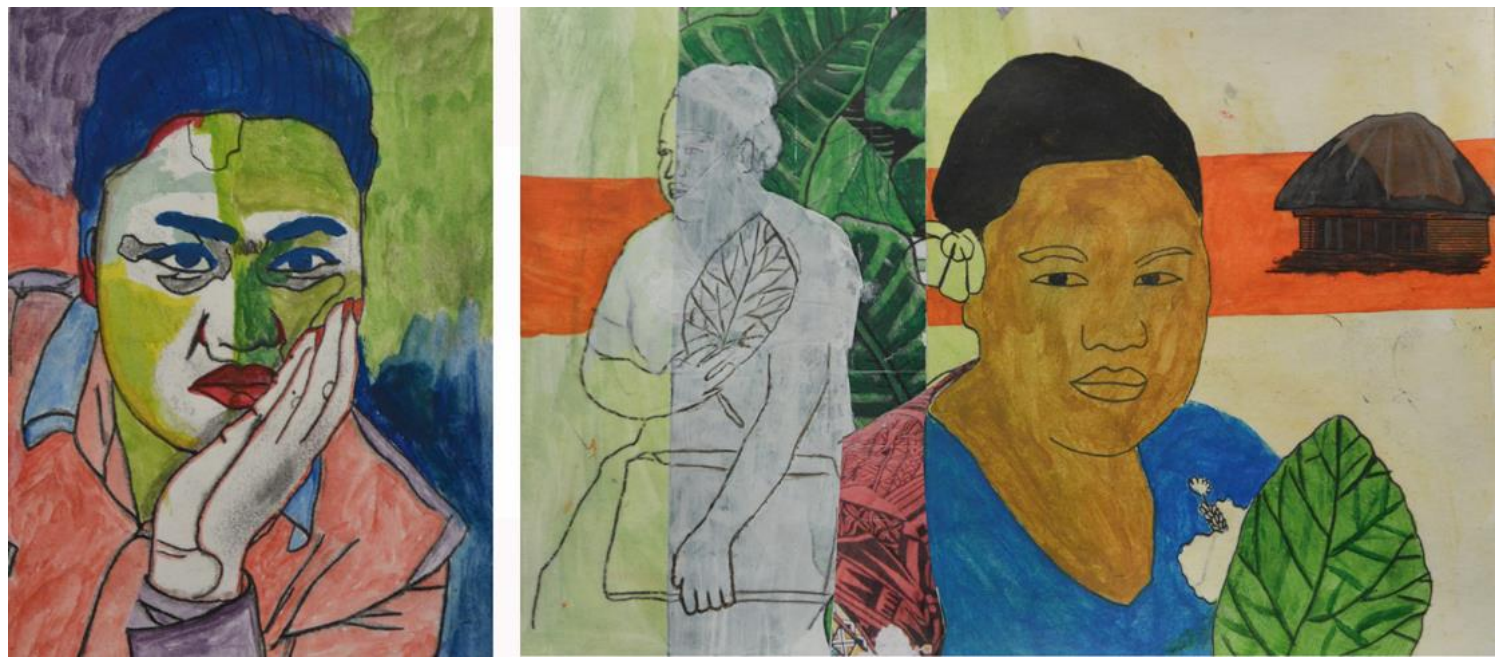

Figure 3. Vera, Samoan, 17
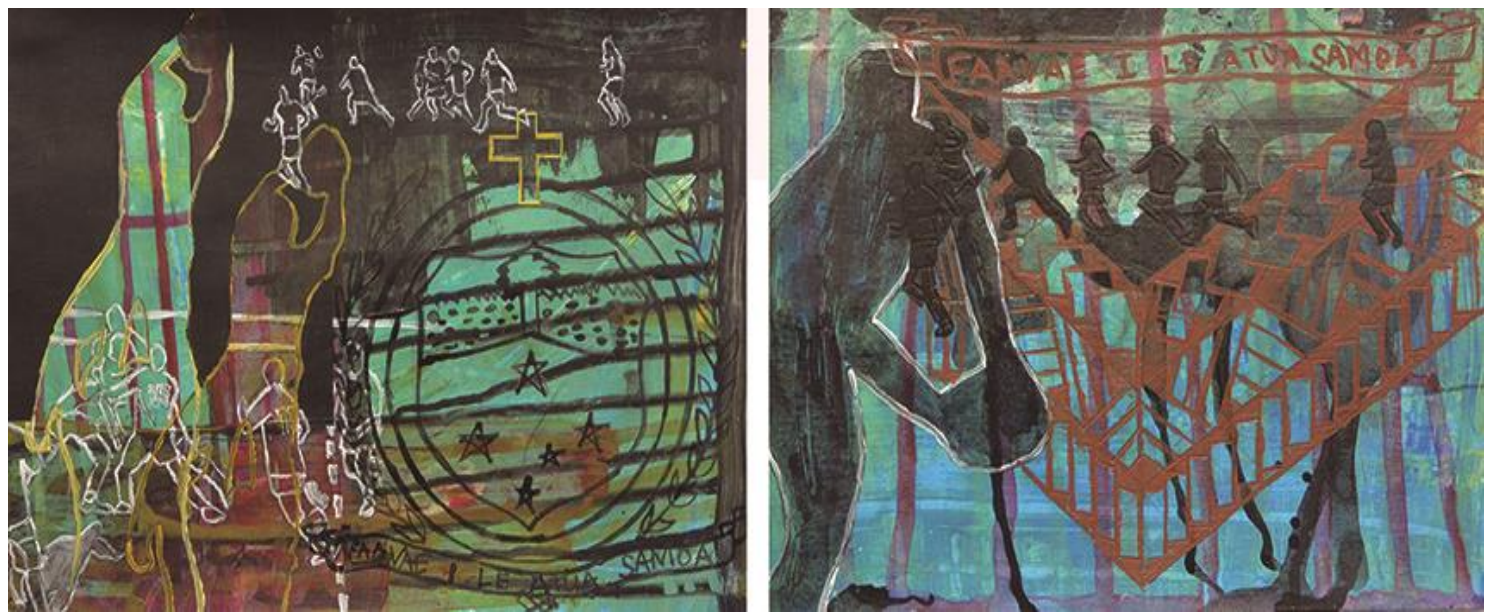

Figure 4. Ah Sam, Samoan, 17

Jacqui explained that many Samoan students, although New Zealandborn, are very proud of their heritage. In the painting on the left (Figure 4), Ah Sam validates his patriotism by depicting the Samoan coat of arms. Bearing the motto "Faavae i Le Atua Samoa" ("God be the Foundation of Samoa"), the coat of arms contains five stars representing the constellation of the Southern Cross, the sea with a coconut palm issuing therefrom, a shield surmounted by a gold cross superimposed on two concentric circles of the world, and olive leaves as in the United Nations Badge. I perceived Ah Sam's representation of the coat of arms in black outline, transposed on a field of green, as signs of his peoples' 
commitment to God and the Samoan nation's passion for the sport of rugby. In the painting on the right, a siapo (tapa cloth) inspired Samoan pattern is incised into thick, sepia-toned impasto paint. The rugby players are layered and outlined to emphasize the dynamic movement of the game.

While there were some European teachers at the school, it had one of the highest numbers of Pasifika and Māori teachers in New Zealand. There was also a large number of Indian teachers. It was clear that Jacqui was thoroughly at home and confident in this caring environment. When I asked her about the importance of teacher disposition for a European-New Zealand Māori teacher working in School B, she said:

Yes, the kind of person you are is very important. For one thing, you have to like being here. You have to enjoy having fun with the students...relating to them, and laughing with them.

A noticeable feature of School B was the sense of understated positivity which pervaded the art department, and the respect that students showed towards each other, their teacher, and me as a visitor. Jacqui's serene, yet quietly assertive, presence was reflected in her students who worked unsupervised in the art room adjacent to the office while we talked and photographed examples of portfolios. From Schools A and B I gained an insight into how the contrasting personalities and styles of the two art teachers were perfectly framed within their contexts, and speculated on what I would find at School C.

\section{Snapshot 3: School C}

Kaitlin, a European-New Zealand woman with a Bachelor of Visual Arts and Graduate Diploma in Secondary Teaching, had taught at School C for six years. This large state co-educational school had a decile rating of 3 and an enrolment of 1,892 students of whom 941 were Pasifika (50\%), predominantly Samoan, then Tongan, Cook Islands Māori, Niuean and Tokelauan. After Pasifika, the next largest ethnic groups were Māori (24\%), Asian (15\%) and European (9\%). Kaitlin's explanation of the mission statement illustrates the school's stance on inclusiveness.

Our forceful values are respecting each other, striving for academic and self-excellence, whanaungatanga...sharing family values and embracing each other's cultures, and akoranga...that's the education side of it. Although we have a largely Pasifika roll, and Mãori, we have a culture where we are trying to foster a whanau system...the idea that although we may come from different cultures we belong to one family.

Kaitlin spoke respectfully about the school's community. Despite a perception that parents weren't concerned about their child's education, Kaitlin was adamant that they were, although this was often hindered by family circumstances in this low socio-economic area. The school had a whanau 
process whereby families meet a tutor teacher who builds a relationship with them and introduces them to their child's subject teachers. At Kaitlin's weekend art workshops for year 11-13 students, parents are encouraged to call by. An end-of-year exhibition of senior art students' portfolios provides further opportunity to connect with families. A feature of Kaitlin's teaching is ensuring that students' prior knowledge is used:

Cultural diversity is at the centre of my planning at every level. Students are proud of their heritage, they're proud of their cultures...they're actually show offs when it comes to their culture. By planning around that we get results because they have a sense of empowerment and buy into it. It's nice to hear conversations around the classroom, like "oh, what do you do in your culture?" so they're sharing that knowledge with their peers.

When Kaitlin meets her year 9 students for the first time she begins with a mihi (a style of greeting drawn from Māori culture) so students know who she is and where she comes from. She stated,

That's how they feel they make a connection. Then we do a zentangle...like a doodle page but they have to include five symbols of what they think represents them, and then share it with the class. They all say, "Oh no, I don't want to talk", and all of a sudden they actually don't mind talking about themselves!"

Kaitlin's year 9-10 programs focus specifically on the differing cultures of students. She explained that if the class is doing something they really enjoy, it's a way of managing behavioral problems. Her units provide opportunities for students to learn about "patterns" that feature in different cultures. These include the circular, symmetrical Indian rangoli patterns that are made on the floor using materials such as colored rice and dry flour; Pasifika tapa/barkcloth patterns that are distinctive to each Pasifika ethnic group; Māori patterns that are woven to make tukutuku panels for meeting houses; and henna/mehendi patterns that are significant for Indian women. Each cultural study provides the starting point for the students' art making. Kaitlin's approach is "to make sure I'm using the students, their prior knowledge, like some of the girls teaching the other students specific henna designs they can use. They become the teachers and I become the learner."

At year 11, the program broadens to the wider community and environmental issues. In this unit, students focused on local beaches, the decline of the bird population, and the impact of the community on the local environment. They select an endangered bird, make cultural patterns based on Pasifika and Māori forms to "protect" that bird, and include salutations such as "kia kaha" (be strong) and "peace." Although the program is class-wide, the approaches I observed of students' mixed media works varied widely. Nicola's subtle depiction in chalk of sea and sand as a metaphor for protecting the local beach (Figure 5a) is complemented by her sensitive use of the scratch-back technique to capture the natural elements of the endangered Tui bird in its environment. In contrast, Keith uses symbolic Māori kowhaiwhai and Samoan patterns in his lino-print to 
symbolize waves, beach and shoreline (Figure $5 b$ ). His Tui bird stands proudly in a protective, glowing arc.

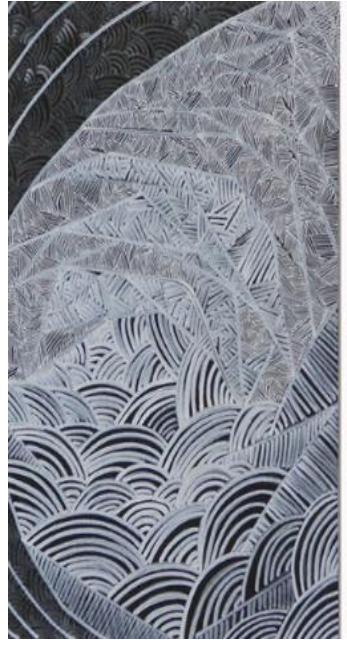

Figure 5a. Nicola, Cook IslandsSamoan, 16

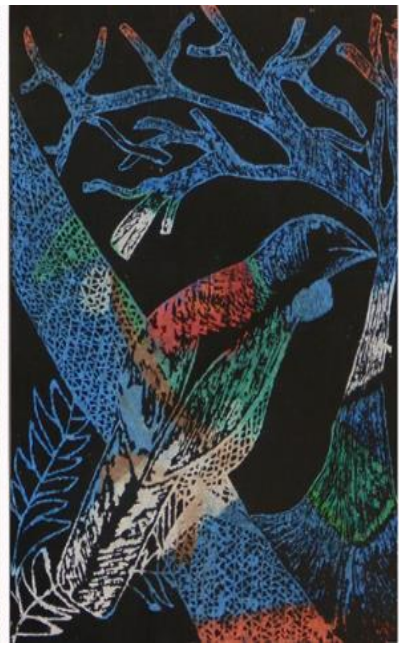

Figure 5b. Keith, Samoan, 15

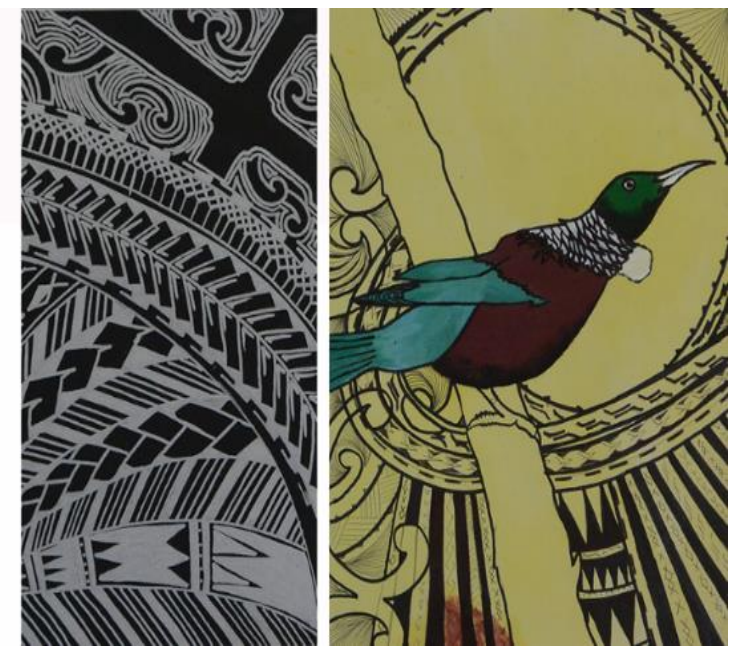

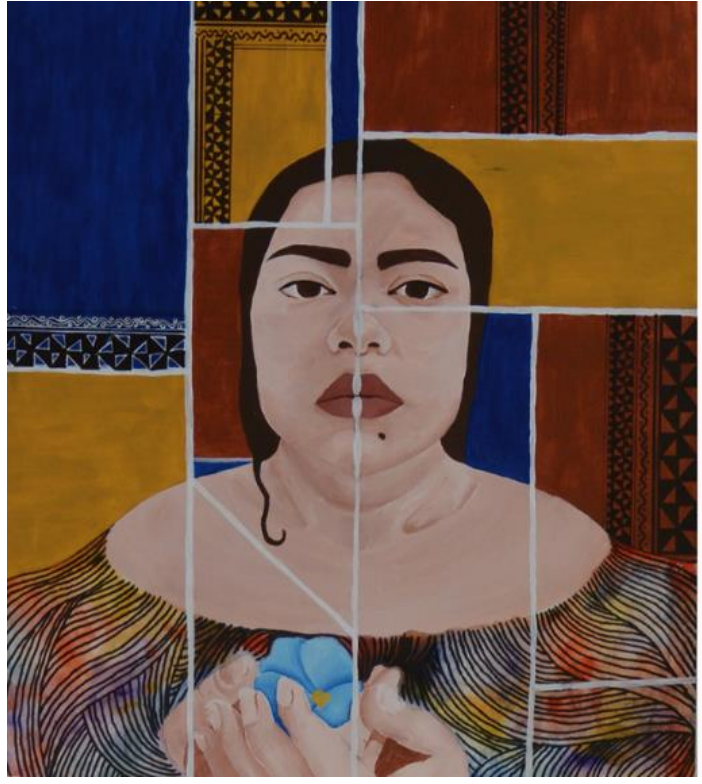

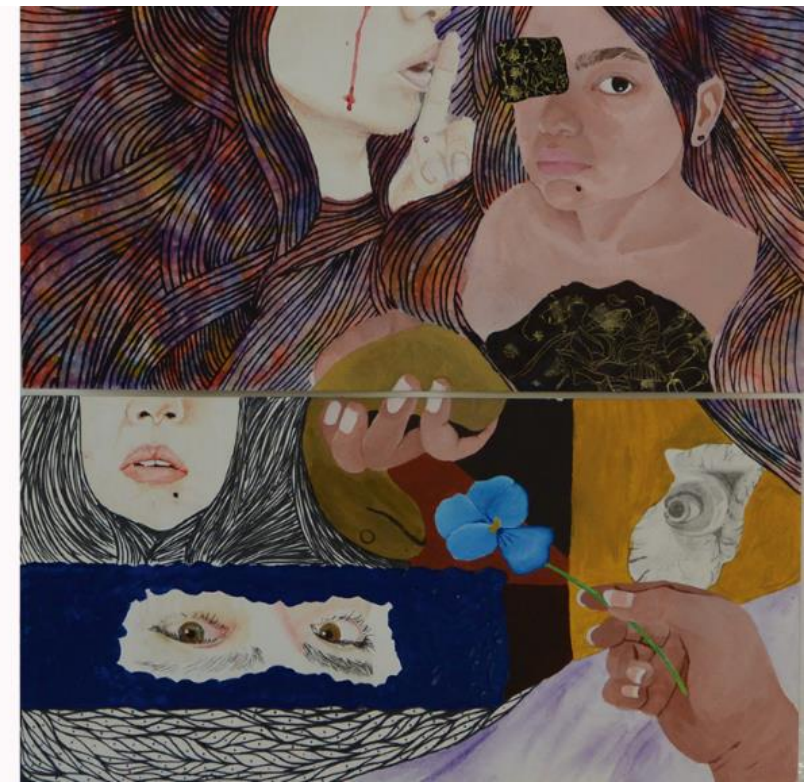

Figure 6. Jade, Cook Islands Māori, 17

At year 12, Kaitlin's students focus on "Symbolic Portraits", beginning with objects with which they identify. They are introduced to how artist models, such as Frida Kahlo and Rita Angus, treat symbolism in portraiture. The art works I observed by students from many cultures, including Pasifika, Māori, Indian and Middle Eastern, reflected the individuality of each student. For her striking selfportraits (Figure 6), Jade was inspired by the line and ink washes on woven 
cloaks depicted by Māori artist, John Bevan Ford. Kaitlin explained that "Jade really liked the symbolic gesture with the flower and her hair became the cloak...and because of the community she grows up in, the grid format containing the Pasifika patterns and tapa-effect is her anchor." I was struck by Jade's frank depiction of herself, with her ample Polynesian frame and mole above her chin. The absence of idealization added power to these beautiful selfportraits. Kaitlin commented, "It's like a self-identity unit in some respects because I don't think the students realize exactly who they are until they start doing this."

When asked if she thought teacher disposition was a significant part of teaching at School C, Kaitlin was adamant that "if a teacher's attitude is narrow, if you're not open to new ideas and learning from students, it's not going to work at this school." She had seen teachers teaching what they wanted to teach and how students felt they were not being heard. She concluded, "If they don't buy into it results are pitiful and behavior is poor." Kaitlin grew up in School C's multicultural community and feels at home there. With a supportive family behind her, Kaitlin is dedicated to the school, its students and their community. She places great emphasis on "growing really good relationships with students" and keeping in touch with them beyond school. It was clear that Kaitlin, herself, enacted the importance of "embracing the culture, running with it, enjoying it, accepting it and growing it." She concluded that teachers at School C have to be prepared to give a lot of themselves first and foremost. I was keen to discover whether this was evident in Matthew's approach to culturally inclusive practices at School D.

\section{Snapshot 4: School D}

Matthew, a European-New Zealand male with a Master of Fine Arts and Graduate Diploma in Secondary Teaching, was head of art at School D and had been teaching over 30 years. School D, a decile 1 state co-educational school, had an enrolment of 721 students of whom 570 identified as Pasifika (79\%). The majority were Samoan (27\%), followed by Cook Islands Māori (19\%) and Tongan (16\%), with smaller numbers of Niuean, Fijian and Tokelauan. Along with four European students there were refugee students from South East Asia, India, and Middle Eastern countries. Matthew explained that the school's philosophy focused on the wellbeing of students, with strong support services in terms of doctors, nurses and counsellors because of the community's needs. He emphasized the strong culture of Māori and Pasifika languages and a determination that all Pasifika students achieve. Most students speak their own language at home, giving them a greater sense of identity and connectedness with their own culture.

The art program at School D is scaffolded from years 9-13, each with a distinct focus. Year 9 art begins with a pattern-based unit where color and strong techniques are used to generate success. At year 10 emphasis is on Key Competencies in the curriculum, particularly "managing self," "relating to others," 
and "participating and contributing." Matthew spoke of how he has to prepare students and give them confidence for senior art examinations at years 11-13. $\mathrm{He}$ explained that "the Pasifika students love working together, they're very happy in the art room, but even happier when they're engaged... and that's what we all want to get a good result."

A feature of Matthew's teaching is transitioning students from being dependent on him at year 11 to a stage where they develop their own ideas at years 12-13. He explained that he had "found ways to staircase them through." One strategy was to show examples of previous portfolios made by their siblings, cousins, friends, and even aunts and uncles. This helps them understand what lies ahead. When I asked Matthew whether he consciously thinks about the students when planning, he said he responds carefully to their feedback. He has learnt from experience that when he shows the right examples, "every student gets a gain from it and that's what I want. I just grow what works and what the students enjoy." Matthew explained that the concept of individual ethnicities of students, and what they are interested in, is very important to him.

They want to tell stories about themselves, but they don't want to tell it like they think they should tell it. I've learnt to accept the student voice. I know they want to do something and I think, oh I don't think you should be doing that...and l've had to let go and let them have a shot in their own way. That's very important for a teenager and you've got to back them up and try and support them.

Matthew gave an example of the stories his students like to tell:

For boys it's mostly about rough and tumble... any bodily contact, fighting, wrestling, dancing...culture works really well as a topic strand, and so does religion....and l've managed to take the fighting into animé which is much more digestible. I'm anti-bullying and I don't like looking at images of physical violence. And they want to do sport as well, especially basketball.

Matthew selects artist models that resonate with themes students want to explore. A favorite is Jon Cattapan whose work, which is generated on the internet, includes political and social representations of the urban environment. But it is this artist's techniques of using dots and lines, outlines of figures and blocks of color that students use to give a sense of dynamism to their work. Students use elements of movement, and dramatic contrasts of light and shadow to express their cultural milieu. Matthew described the work of a 15-year-old Cook Islands Māori boy, Andre (Figure 7), as "high and low art and popular culture blending together in an animé theme, and that whole powerball thing...lots of physical contact...he's dealing with what he wants to deal with." I was particularly struck by Andre's use of perspective, foreshortening and scale, which added intensity to his messages. 

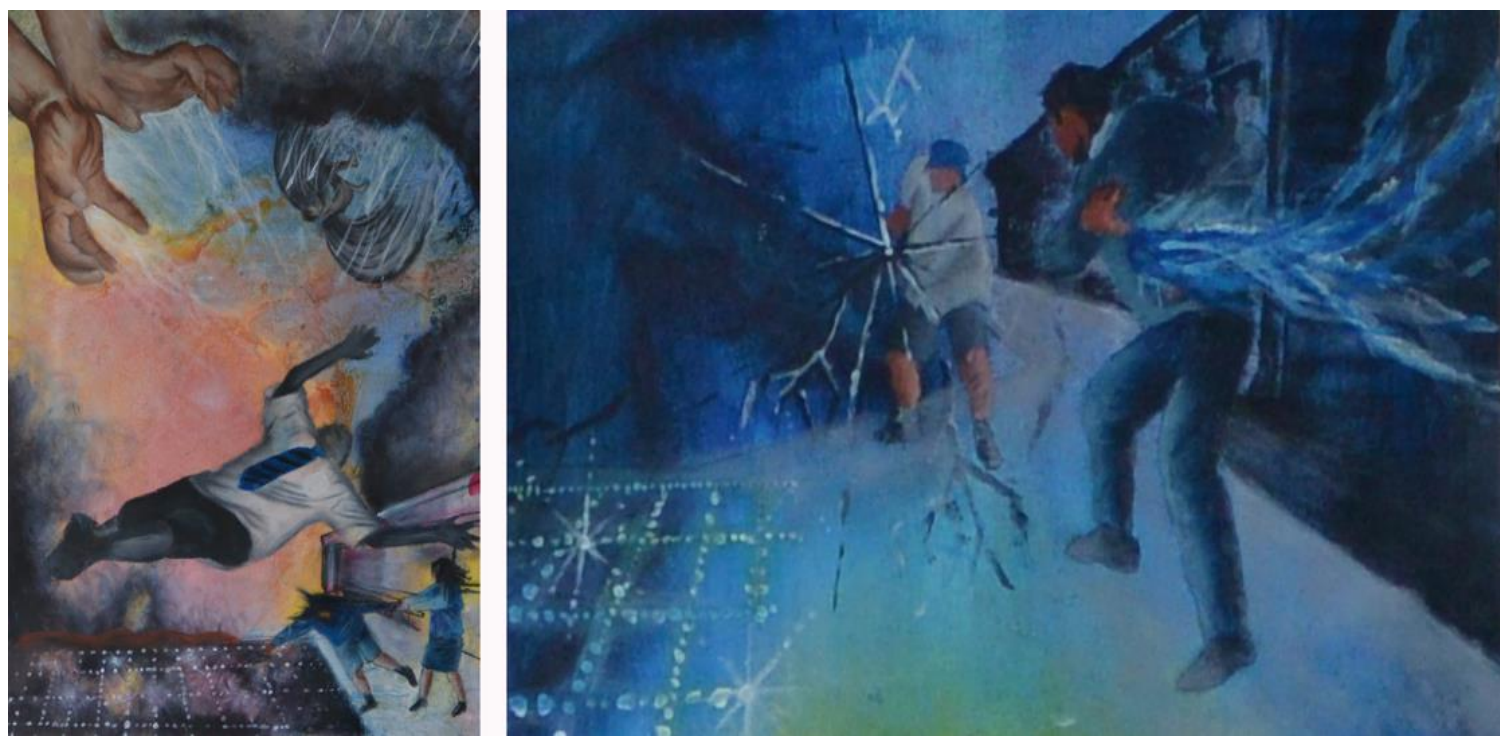

Figure 7. Andre, Cook Islands Māori, 15

Matthew said, "I don't have problems getting students to generate work. They take photos of each other, they do leapfrogs, it's just fantastic, but it's all about the hook in isn't it, especially at year 11?" This pedagogical approach was evident in the mixed media paintings (Figure 8) by 16 year old Samoan boy, Kapiti. His primary focus on the dynamic footwork of hip hop dancing and playing basketball is captured through a personal interpretation of Cattapan's techniques.
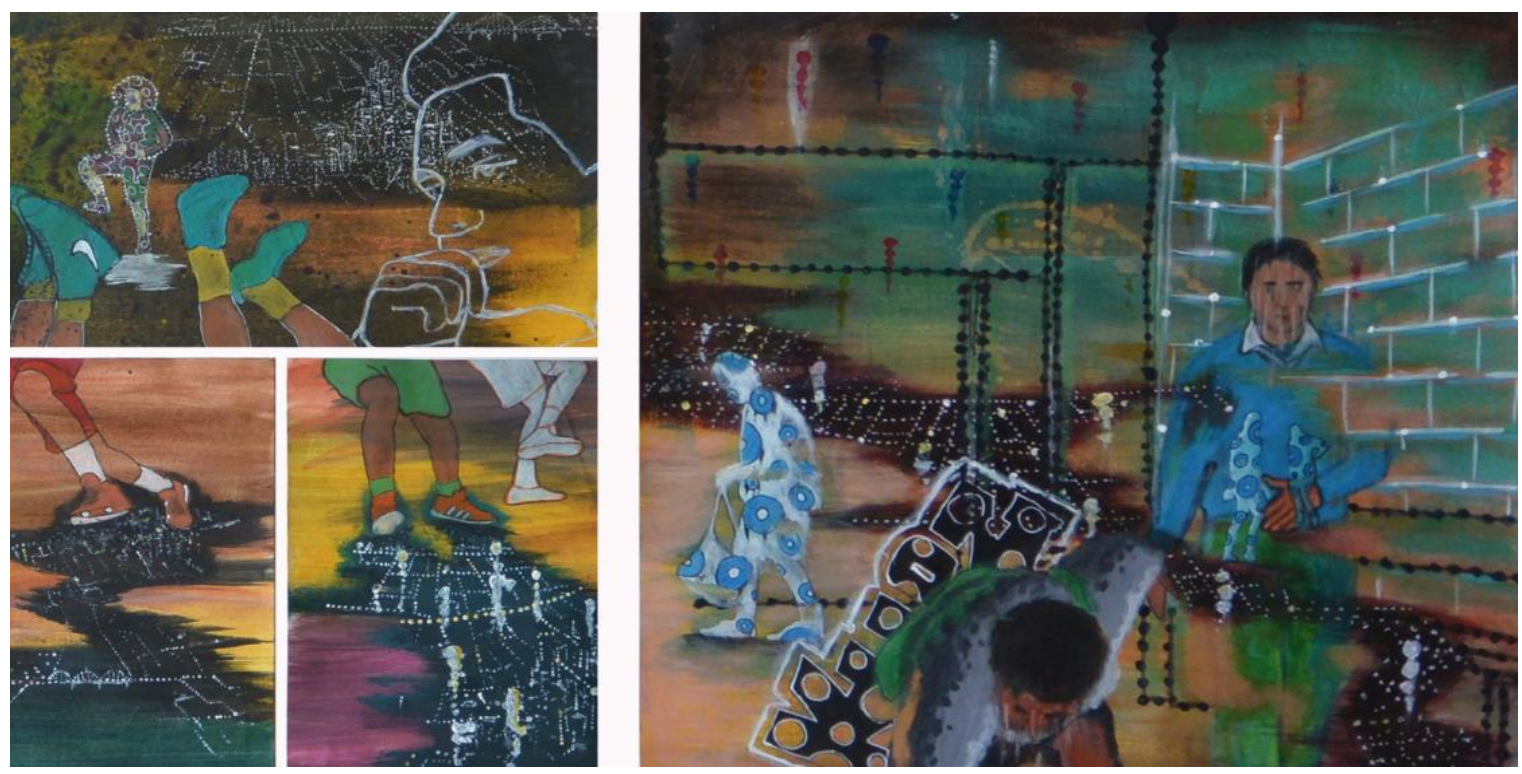

Figure 8. Kapiti, Samoan, 16 
In response to my query about his relationship with the Pasifika students, Matthew said they accept him as a European-New Zealander: "They're not critical of difference." He laughingly described himself as "an old White man," but he clearly belongs in this environment, identifies with students and has developed a deep understanding of them. "I'm actually quite strict in the way students have to behave, but I'm gentle with them, too, and it works." This was evident in the warmth with which he talked about working with, and for, the students.

\section{Discussion}

The findings from the four "snapshots" draw from data collected from three European-New Zealand and one European-New Zealand Māori art teacher who work in low decile secondary schools where Pasifika students comprise the largest ethnic group. The findings exemplify how the four teachers use the visual arts effectively to empower their Pasifika students to learn about Pasifika peoples' art and culture and to make art works that express their collective Pasifika and individual identities. Underpinning the study was literature about Pasifika learners (Ferguson et al., 2008; Fletcher et al., 2009; Nash, 2004; Si'ilata, 2014); multicultural education (Erickson, 2006; Grant \& Sleeter, 2006; Hanley \& Noblit, 2009; Nieto \& Bode, 2012; Sleeter, 2008), and culturally inclusive visual arts education (Bianchi, 2011; Bolin \& Blandy, 2011; Desai \& Chalmers, 2007; Duncum, 2008; Freedman \& Stuhr, 2004). A number of commonalities emerged from the study about the beliefs and values of the four teachers and their pedagogical approaches for planning and teaching to support Pasifika students achieve success through the visual arts.

\section{The Art Teachers' Values and Beliefs}

It was apparent from their interviews that the four art teachers firmly believed in the mission statements and philosophies of their schools. In accord with Nash (2004), each was confident that the students' cultures were respected by the school, and the degree of similarity between the culture of the community and the values of that school were closely aligned.

While Ferguson et al. (2008) contend that few opportunities are given to Pasifika students to create their own identities, the findings show that all four art teachers valued diversity, believed they were engaging in culturally responsive pedagogies, and encouraged students to respect each other's cultures. Kaitlin, at School D, described how in art units for which particular knowledge is required "they become the teachers and I become the learner." Strong relationships, and an intimacy of engagement between the art teachers and their Pasifika students, collectively and as individuals, were prominent. This aligns with Hanley and Noblit's (2009) assertion that "culturally responsive programming and positive 
racial identity can promote achievement and resilience" (p. 83). Contrary to the supposition by Ferguson et al. (2008), these teachers supported Pasifika learners to be themselves and to see themselves and their culture reflected in the classroom. Each teacher believed they understood "the multiple worlds Pasifika students live in" (Si'ilata, 2014, p. 2).

Deficit thinking about Pasifika learners was not evident, even when Martin at School A said, with honesty, "They can be lazy and drive me mad at times." Above all, the four teachers had high expectations for Pasifika learners. Each emphasized a drive towards students achieving success and "managing self," one of the Key Competencies in the New Zealand Curriculum (MoE, 2007). Overall, Martin, Jacqui, Kaitlin and Matthew believed their attitudes and overall dispositions aligned with their school's culture and students and that they "fitted in."

\section{Visual Arts Education for Pasifika Students}

The support by the four art teachers for the mission statements and philosophies of their schools was, in turn, reflected in the "vision" for their art departments. Each teacher scaffolded their visual arts programs from years 9-13 to build skills, techniques, visual literacy, self-efficacy, and student confidence. Year 9-11 programs included a focus on Pasifika subject matter, symbols and techniques. At years 12-13, in particular, the stories told through the examples of students' art works show that these Pasifika students had been encouraged to be themselves and draw upon aspects of themselves, including their ethnic differences, cultural identities, individuality, and cultural milieu.

These teachers believed that subject matter which resonated with Pasifika students and gave them a voice was key to their engagement and success. They all built on Pasifika students' knowledge and experiences, and on using that knowledge and those experiences to teach their peers. Every teacher believed their visual arts programs enabled Pasifika students to be themselves and that their cultures were reflected in the classroom. Above all, they were certain that their visual arts programs empowered Pasifika students to express their ethnic and cultural identities and tell their own stories, particularly at years 12-13. It was clear that these art teachers felt responsible for their Pasifika students, valued diversity, respected their cultures, had high expectations, and built on students' experiences (Alton-Lee, 2003; Fletcher et al., 2009; Rubie-Davies, 2008).

The decision to invite the art teachers to bring to their interviews examples of students' art works which they believed reflected their responsiveness to the ethnic and cultural diversity of the students they teach was in response to Leavy's (2009) advocacy of the power of the image to provide "a significant source within which researchers can discern patterns pertaining to individuals and society" (p. 216). I found that the students' art works illustrated a broader cultural reference than ethnicity. Some resembled "texts," a construction of 
symbolic signs through which the students represented themselves (Cohen, 1985). In others, there was evidence of their interest in popular forms of visual culture and material culture (Bolin \& Blandy, 2011; Duncum, 2008; Freedman \& Stuhr, 2004). The Pasifika students' art works (Figures 1-8) attest to the opportunities given to them by the teachers to create their own identities.

\section{Conclusion}

This qualitative study set out to understand and describe the world of human experience, in this instance, how four European-New Zealand art teachers working in secondary schools with large Pasifika student populations empowered them to express their individual identities through the visual arts.

The shape and form of this study highlighted potential limitations. First, the art teachers who volunteered to participate undoubtedly did so because they held a particular interest in the research question. Moreover, the majority of the 28 teachers who agreed to be interviewed, including the four who feature in this article, taught in low to mid-decile secondary schools with ethnically diverse students. Although beyond the scope and timeframe of the study, a third limitation is that the voices of students were not sought. Additionally, an oversight on the students' consent forms was not inquiring whether they were New Zealand-born, a significant statistic reported by the Royal Society of New Zealand (2014). The foremost limitation could be perceived as the issue of validity, especially since validity of interpretations and meanings has long been questioned in debates over the legitimacy of qualitative research (Denzin \& Lincoln, 2011). In this study it was impossible to escape the subjective experience. I acknowledge that this small-scale qualitative study is not generalizable in the traditional sense. Rather, it has verisimilitude through "the creation of a realistic, authentic, life-like portrayal" (Leavy, 2009, p. 57). It has features that make it highly valuable to the art education and Pasifika communities in New Zealand.

The knowledge generated by the study is significant in its own right. The stories told through the voices of these art teachers and visualized through examples of art works by their Pasifika students, encapsulate the importance of building relationships between predominantly European teachers and the increasingly diverse youthful population, not only in visual arts education but in other curriculum areas. As a mark of respect, I invited Pasifika colleagues at the Faculty of Education to preview the draft. Manutai Leaupepe, of Cook Islands, Tahitian and Kiribati descent, was "deeply moved by it" and was especially drawn to Vera's paintings (Figure 3). Tanya Wendt Samu (see Ferguson et al., 2008), Associate Dean-Pasifika, and of Samoan descent, assured me that this study would make a valuable contribution to their work with Pasifika students. Albeit small in scale, the study has the potential to make an innovative contribution to the field. It fills a gap in the literature. It has the potential of transferability of the 
rich and empowering experiences of these art teachers to similar settings, both elsewhere in New Zealand, and in other nations.

\section{Notes}

1. In the 2013 New Zealand Census, "European" refers to New Zealanders of European descent and to other European peoples.

2. Where a person reported more than one ethnic group in the $2013 \mathrm{New}$ Zealand Census they were counted in each applicable group, thus the population statistics are not rounded off to $100 \%$.

3. The year levels in New Zealand schools are years 9-13, with most students entering as 13 year olds. Year 13 students are usually 17 or 18 .

4. A feature of visual arts examinations at years $11-13$ is the study of "artist models" as inspiration for the students' own art making.

\section{References}

Alton-Lee, A. (2003). Quality teaching for diverse students in schooling: Best evidence synthesis iteration. Wellington, NZ: Ministry of Education.

Auckland Council. (2013). Pasifika Auckland: Social and Community Development Forum. Auckland, NZ: Author.

Bianchi, J. (2011). Intercultural identities: Addressing the global dimension through art education. International Journal of Art \& Design Education, 30(2), 279-292.

Bolin, P. E., \& Blandy, D. (Eds.). (2011). Matter matters: Art education and material culture studies, Reston, VA: National Art Education Association.

Cohen, A. (1985). The symbolic construction of community. New York, NY: Routledge.

Denzin, N. K., \& Lincoln, Y. S. (2011). (Eds.). The Sage handbook of qualitative research ( $4^{\text {th }}$ ed.). Thousand Oaks, CA: Sage.

Desai, D., \& Chalmers, G. (2007). Notes for a dialogue on art education in critical times. Art Education, 60(5), 6-12.

Duncum, P. (2008). Exploring visual culture: Definitions, concept, contexts. The Journal of Aesthetic Education, 42(1), 118-120.

Education Review Office. (2012). The New Zealand curriculum principles: Foundations for curriculum decision-making. Wellington, NZ: Author. 
Erickson, F. (2006). Culture in society and in educational practices. In J. A. Banks \& C. A. M. Banks (Eds.), Multicultural education: Issues and perspectives (6 ${ }^{\text {th }}$ ed.), (pp. 33-61). Hoboken, NJ: Wiley.

Feistritzer, C. E. (2011). Profile of teachers in the U.S. 2011. Washington, DC: National Center for Education Information.

Ferguson, P., Gorinski, R., Wendt-Samu, T., \& Mara, D. (2008). Literature review on the experience of Pasifika learners in the classroom. Wellington, NZ: Ministry of Education.

Fletcher, J., Parkhill, F., Amosa, F., Leali'ie'e, T. T., \& O'Reagan, B. (2009). Pasifika students: Teachers and parents voice their perceptions of what provides supports and barriers to Pasifika students' achievement in literacy and learning, Teaching and Teacher Education, 25, 24-33.

Freedman, K., \& Stuhr, P. (2004). Curriculum change for the 21st Century: Visual culture in art education. In E. W. Eisner \& M. D. Day (Eds.), Handbook of research and policy in art education (pp. 815-828). Mahwah, $\mathrm{NJ}$ : Lawrence Earlbaum.

Grant, C., \& Sleeter, C. (2006). Turning on learning: Five approaches to multicultural teaching plans for race, class, gender and disability ( $4^{\text {th }}$ ed.). Upper Saddle River, NJ: Prentice-Hall.

Hanley, M. S., \& Noblit, G. W. (2009). Cultural responsiveness, racial identity and academic success: A review of the literature. A paper presented for the Heinz Endowments, June 2009. Retrieved from http://www.heinz.org/ userfiles/library/culture-report_final.pdf

Landsman, J., \& Lewis, C. W. (Eds.). (2006). White teachers, diverse class rooms: A guide to building inclusive schools, promoting high expectations, and eliminating racism. Sterling, VA: Stylus.

Leavy, P. (2009). Method meets art: Arts-based research practice. New York, NY: The Guilford Press.

Ministry of Education. (2007). The New Zealand curriculum. Wellington, NZ: Author.

Ministry of Education. (2010). Teu le va: Relationships across research and policy in Pasifika education. Wellington, NZ: Author.

Nash, R. (2004). Teacher effectiveness and the explanation of social disparities in educational achievement, New Zealand Journal of Teachers' Work, 1(1), 42-51.

Nieto, S., \& Bode, P. (2012). Affirming diversity: The socio-political context of multicultural education ( $6^{\text {th }}$ ed.). Boston, MA: Allyn \& Unwin.

Royal Society of New Zealand. (2014). Our Futures Te Pae Tawhiti: The 2013 Census and New Zealand's changing population. Retrieved from http://www.royalsociety.org.nz/our-futures 
Rubie-Davies, C. (2008). Teacher expectations. In T. L. Good (Ed.), 21 st Century education: A reference handbook (pp. 254-262). Thousand Oaks, CA: Sage.

Si'ilata, R. (2014). Va'a Tele: Pasifika learners riding the success wave on linguistically and culturally responsive pedagogies. Unpublished PhD thesis, The University of Auckland. Retrieved from http://hdl.handle.net/ 2292/23402

Sleeter, C. E. (2008). Preparing white teachers for diverse students. In M. Cochran-Smith, S. Feiman-Nemser, D. Mclntyre, \& K. Demers (Eds.), Handbook of research on teacher education: Enduring questions in changing contexts (pp. 559-582). New York, NY: Routledge.

Smith, J. (2007). Art education in New Zealand: Issues of culture, diversity and difference. Unpublished doctoral thesis, The University of Auckland, Auckland, New Zealand.

Smith, J. (2010). Biculturalism and multiculturalism: Competing tensions in visual arts education in Aotearoa-New Zealand, International Journal of Multicultural Education, 12(2), 1-18.

Statistics New Zealand. (2014). 2013 Census QuickStats about culture and identity. Retrieved from http://www.stats.govt.nz

The World Directory of Minorities and Indigenous Peoples (2015). Retrieved from http://www.minorityrights.org/minorities/pacific-islanders/

Weber, S. (2008). Visual images in research. In J. G. Knowles \& A. L. Cole (Eds.), Handbook of the arts in qualitative research: Perspectives, methodologies, examples, and issues (pp. 41-53). Thousand Oaks, CA: Sage.

\section{Author Contact}

Jill Smith: j.smith@auckland.ac.nz

The University of Auckland, Private Bag 92019, Auckland 1142, New Zealand 